\title{
GENETIC DIVERSITY OF Agave cupreata TREL. \& BERGER. CONSIDERATIONS FOR ITS CONSERVATION
}

\author{
DIVERSIDAD GENÉTICA DE Agave cupreata TREL. \& BERGER. CONSIDERACIONES PARA SU \\ CONSERVACIÓN
}

\author{
Alejandro Martínez-Palacios ${ }^{1 *}$, Juan M. Gómez-Sierra ${ }^{1}$, Cuauhtémoc Sáenz-Romero ${ }^{1}$, Nidia Pérez-Nasser ${ }^{2}$ y \\ Nahúm Sánchez-Vargas ${ }^{1}$
}

\begin{abstract}
${ }^{1}$ Instituto de Investigaciones Agropecuarias y Forestales, Universidad Michoacana de San Nicolás de Hidalgo. Km 9.5 Carretera Morelia-Zinapécuaro. 58880, Tarímbaro, Michoacán, México. Phone +(52)(443) 334-0475 ext. 119, fax ext. 200. ${ }^{2}$ Centro de Investigaciones en Ecosistemas, Universidad Nacional Autónoma de México. Antigua Carretera a Pátzcuaro No. 8701, Col Ex-Hacienda de San Miguel de la Huerta. 58190, Morelia, Michoacán.

*Corresponding author (apalacios56@gmail.com)
\end{abstract}

\section{SUMAMRY}

Agave cupreata Trel. \& Berger is an endemic plant naturally distributed in the Balsas Depression, a semiarid region in the states of Guerrero and Michoacán in Southwestern México. Their populations are heavily decimated because mature individuals just before their single life flowering period are harvested to produce mescal, an alcoholic beverage. The genetic variation among and within 12 natural populations was examined for nine isozyme loci. Results indicate high average proportion of polymorphic loci $(93 \%)$ and expected heterozygosity $\left(H_{\mathrm{e}}=\mathbf{0 . 4 6 7}\right)$, with an excess of observed heterozygotes in relation to Hardy-Weinberg expectations $\left(H_{0}=0.521, F_{\mathrm{IS}}=-0.1179\right)$. These results represent the largest heterozygosity reported for Agave species endemic to México. There is also a statistically significant genetic differentiation among populations $\left(F_{\mathrm{ST}}=0.042\right)$. An UPGMA dendrogram reveals the absence of a geographic pattern, as confirmed by a Mantel test $(r=-0.110, P=0.769)$, which did not show significant isolation by distance. Estimated minimum viable effective population size was very large $\left(N_{e}=16,165\right)$, larger than in any other known natural population. To protect the natural genetic variation, it is suggested to design and manage $A$. cupreata natural populations as forest genetic resource conservation units (FGRCUs) using realistic and modest $N_{e}$ sizes, perhaps between 500 and 5000 plants, ideally with intermediate plantations that could serve as pollinator corridors. Commercial plantations and $e x$ situ FGRCUs need to be established to gradually develop a sustainable management, perhaps at higher altitudes than current locations, as a management measure for adaptation to the climatic change.

Index words: Agavaceae, population genetics, minimum viable effective population size.

\section{RESUMEN}

Agave cupreata es una planta endémica que se distribuye en la Depresión del Balsas, una región semiárida de los Estados de Guerrero y Michoacán, al sur-occidente de México. Sus poblaciones están muy diezmadas debido a que los individuos maduros se cosechan justo antes de su floración, que ocurre sólo una vez en su vida, para producir mezcal, una bebida alcohólica. La variación genética entre y dentro de 12 poblaciones naturales fue examinada en nueve loci isoenzimáticos. Los resultados indican un promedio muy elevado de proporción de loci polimórficos $(93 \%)$ y de heterocigosidad esperada $\left(H_{\mathrm{e}}=0.467\right)$, con un exceso de heterocigotos observados en relación con lo esperado bajo el equilibrio de Hardy-Weinberg $\left(H_{0}=0.521, F_{I S}=-0.1179\right)$. Estos resultados de heterocigosidad son la más altos reportados en especies de Agave endémicas de México. También hay una diferenciación genética entre poblaciones estadísticamente significativa $\left(F_{\mathrm{ST}}=0.042\right)$.
Un dendrograma UPGMA revela la ausencia de un patrón geográfico, confirmada por una prueba de Mantel $(r=-0.110, P=0.769)$, que demostró que no hay un significativo aislamiento por distancia. El tamaño mínimo efectivo viable de la población fue muy grande $\left(N_{\mathrm{e}}=\right.$ $16,165)$, más grandes que en cualquier otra población natural conocida. Para proteger la variación genética natural de $A$. cupreata se sugiere diseñar y gestionar la conservación de poblaciones naturales como unidades de conservación de recursos genéticos forestales (UCRGFs) con tamaños de $N_{e}$ realistas y modestos, tal vez entre 500 y 5000 plantas, idealmente con plantaciones intermedias que podrían servir como corredores de polinizadores. Se necesita establecer plantaciones comerciales y UCRGF ex situ para desarrollar gradualmente un manejo sustentable, tal vez a altitudes mayores que a la que se encuentran las localidades actuales, como una medida de manejo para adaptarse al cambio climático.

Palabras clave: Agavaceae, genética de poblaciones, tamaño efectivo mínimo de población viable.

\section{INTRODUCTION}

Agave cupreata Trel. \& Berger is an endemic plant of the Agavaceae family (Crenatea group, subgenus Agave), now classified as a subfamily of the expanded Asparagalean families (Chase et al., 2004). It is naturally distributed in the interior uphill slopes (1220 to $1850 \mathrm{~m}$ of altitude) of the Balsas Depression, a semiarid region in the states of Guerrero and Michoacán in Southwestern México (Gentry, 1982). Many of the natural populations are heavily decimated because mature whole individuals are harvested just before flowering, when the sugar concentration is at its maximum, to produce mescal in local artisan distilleries, a traditional liquor similar to the well known Mexican tequila (Colunga-GarcíaMarín and Zizumbo-Villarreal, 2007; Zizumbo-Villarreal and Colunga-GarcíaMarín, 2007). Harvesting prevents the species reproduction because $A$. cupreata is a semelparous plant (it can reproduce sexually only once in their life time) and it does not reproduce vegetatively. The effect of harvesting in the population demography is aggravated because plants need between 7 and 15 years to reach their sexual maturity (Illsley et al., 2007). Apparently, the overexploitation of the natural populations is more severe in the state of Michoacán than 
that in Guerrero. There are a few examples of well organized Indian communities to conduct some management of the A. cupreata natural populations in the region of Chilapa, Central-East part of the state of Guerrero, with specific rules that contribute to a more sustainable management, such as harvesting no more than $80 \%$ of the individuals at flowering stage, reintroducing seedlings propagated in nurseries and setting aside populations designated as reserves (Illsley-Granich C. 2004; Personal Comm.) ${ }^{1}$.

Local producers of mescal, mainly from the state of Michoacán, recently recognized that their use of natural populations of $A$. cupreata is not sustainable, and gradually began to organize themselves in mescal producer associations that have established approximately 800 ha of plantations (SEDRU, 2009) from seedlings produced in rustic greenhouses without control of seed source. Although such actions are an encouraging start, a more sophisticated management program is required which should combine a sustainable harvesting with a biological conservation program to protect the genetic variation of $A$. cupreata (Eguiarte and Souza, 2007). For reaching this goal, the patterning of genetic variation of natural populations needs to be determined.

Genetic diversity among and within populations of several species of Agave endemic to México has been studied using molecular markers. In general, high levels of expected heterozygosity $\left(H_{\mathrm{e}}\right)$ were observed, and high genetic differentiation among populations $\left(F_{\mathrm{ST}}\right.$ or $\left.G_{\mathrm{ST}}\right)$ in one case, and medium to low in most cases, has been documented: $H_{\mathrm{e}}=0.335$ and $F_{\mathrm{ST}}=0.236$ for Agave victoriaereginae T. Moore (Martínez-Palacios et al., 1999); $H_{\mathrm{e}}=0.394$ and $\theta=0.083$ for Agave lechuguilla (Silva-Montellano and Eguiarte, 2003b); $H_{\mathrm{e}}=0.12$ to $H_{\mathrm{e}}=0.29$ and $G_{\mathrm{ST}}=0.11 \pm 0.02$ for the complex Agave deserti Engelm., A. cerulata Trel. and A. subsimplex Trel. (Navarro-Quezada et al., 2003); and $H_{\mathrm{e}}$ $=0.261$ for Agave angustifolia Haw. (Barraza-Morales et al., 2006). However, to our present knowledge there are no previously published studies of the genetic variability of $A$. cupreata.

The objectives of the present study are: a) estimate levels of variation and genetic structure among and within natural populations of Agave cupreata using isozyme markers, and b) suggest measures of conservation of the genetic diversity of $A$. cupreata.

\section{MATERIALS AND METHODS}

\section{Studied populations and material collection}

Leaves of 37 randomly selected mature healthy individuals of each of 12 natural populations ( 8 from the

\footnotetext{
${ }^{1}$ IIlsley-Granich C (2004) Manejo campesino sustentable del maguey papalote de Chilapa. Informe final de proyecto. Grupo de Estudios Ambientales AC y Comisión Nacional para el Conocimiento y Uso de la Biodiversidad, México D.F. 43 p.
}

state of Michoacán and 4 from Guerrero) were collected along the entire distribution range of $A$. cupreata (Table $1)$. The groups of individual plants represented by the samples are termed populations while the location where a population was collected is called provenance. Leaf samples were transported to the lab in coolers $\left(6^{\circ} \mathrm{C}\right)$, and $3 \mathrm{~cm} \mathrm{x} 3$ $\mathrm{cm}$ samples were stored at $-70{ }^{\circ} \mathrm{C}$ until processed.

\section{Isozyme electrophoresis}

Starch gel electrophoresis and staining protocols were conducted following standard methods (Conkle et al., 1982; Cheliak and Pitel, 1984), with modifications as described by Martínez-Palacios et al. (1999). Sections of fresh, young leaves were crushed into $0.5 \mathrm{~mL}$ of the grinding buffer [3:1 (v:v) mixture of buffer YO from Yeh and O'Malley (1980) and VegII from Pitel and Cheliak (1984)]. The extracts were adsorbed in Whatman No. 17 paper wicks that were applied later to starch gels $11 \%$. Two systems of electrode and gel buffers, and seven enzymes with good resolution were used. A total of 9 loci were analyzed. System LiOH 8 (Soltis et al., 1983; Martínez-Palacios et al., 1999) resolved glutamate oxaloacetate transaminase (Got-1), malic enzymes ( $\mathrm{Me}-2)$, menadione reductase $(M n r-1)$, phosphoglucoisomerase (Pgi-1 and Pgi-2). System C (Stuber et al., 1988) resolved acid phosphatase (Acph-1), glutamate dehydrogenase (Gdh-1), phosphoglucomutase (Pgm-1 and Pgm-2). Gels were electrophoresed at $60 \mathrm{~mA}$ for 7 to $8 \mathrm{~h}$.

Enzymatic systems with more than one locus were numbered according to their mobility relative to the alleles of standard individuals present in all gels and systems. Allelic variants were numbered sequentially from anode to cathode. The numbers of loci and alleles genetically controlling the enzyme activity were inferred from the observed banding patterns and from data on quaternary structure (Wendel and Weeden, 1989). Initially we essayed other loci (Dia1, Dia2, Est1 and Est2) that worked with Agave victoriae-reginae (Martínez-Palacios et al., 1999), but we discarded them because they showed poor resolution with $A$. cupreata extracts. However, since we included Gdh1, Pgm1 and Pgm2, our final number of examined loci (9) was not much different than that used by $A$. victoriaereginae (10 loci).

\section{Data analysis}

we estimated the number of polymorphic loci $(P$, criterion of $95 \%)$, average number of alleles per locus $(A)$, observed $\left(H_{\mathrm{o}}\right)$ and expected $\left(H_{\mathrm{e}}\right)$ heterozygosity under HardyWeinberg equilibrium $\mathrm{Chi}^{2}$ test (Snedecor and Cochran, 1967), exact test of Haldane (1954), Wright's $F$ statistics (Wright, 1965) and their $95 \%$ confidence intervals (using 10000 iterations), genetic distances among populations (Nei, 1978), and a dendrogram was constructed through the unweighted pair group method with arithmetic mean (UPGMA) using the tools of the population genetics program (TFPGA) (Miller, 1997). A Mantel test (Manly, 1987) was performed between genetic and geographic 
Table 1. Mexican localities and genetic parameters of twelve Agave cupreata populations.

\begin{tabular}{cccccccccc}
\hline Population & State ${ }^{\dagger}$ & Municipality & Locality & $\begin{array}{c}\text { Coordinates } \\
\text { Lat. N, Long. W }\end{array}$ & $\begin{array}{c}\text { Altitude } \\
(\mathrm{m})\end{array}$ & $\begin{array}{c}\text { P } \\
(\%)\end{array}$ & A & He & Ho \\
\hline 1 & Mich. & Turicato & Chiquito & $19^{\circ} 21^{\prime}, 101^{\circ} 31^{\prime}$ & 1650 & 100 & 2.9 & 0.526 & 0.605 \\
2 & Mich. & Madero & San Miguel & $1^{\circ} 27^{\prime}, 101^{\circ} 11^{\prime}$ & 1619 & 89 & 2.8 & 0.439 & 0.439 \\
3 & Mich. & Morelia & Llanitos & $19^{\circ} 35^{\prime}, 101^{\circ} 06^{\prime}$ & 1887 & 100 & 2.9 & 0.501 & 0.556 \\
4 & Mich. & Morelia & El Limón & $19^{\circ} 32^{\prime}, 101^{\circ} 03^{\prime}$ & 1811 & 89 & 2.8 & 0.474 & 0.526 \\
5 & Mich. & Charo & Escalera & $19^{\circ} 37^{\prime}, 101^{\circ} 02^{\prime}$ & 1733 & 100 & 2.9 & 0.467 & 0.550 \\
6 & Mich. & Charo & Pie de la Mesa & $19^{\circ} 37^{\prime}, 100^{\circ} 57^{\prime}$ & 1927 & 100 & 2.9 & 0.436 & 0.480 \\
7 & Mich. & Tzitzio & Tembladera & $19^{\circ} 34^{\prime}, 100^{\circ} 57^{\prime}$ & 1800 & 89 & 2.8 & 0.482 & 0.496 \\
8 & Mich. & Jungapeo & Escobas & $19^{\circ} 28^{\prime}, 100^{\circ} 19^{\prime}$ & 1420 & 78 & 2.9 & 0.442 & 0.510 \\
9 & Gro. & E. Neri & Xochipala & $17^{\circ} 48^{\prime}, 99^{\circ} 41^{\prime}$ & 1286 & 89 & 3.0 & 0.485 & 0.567 \\
10 & Gro. & Tixtla & Tixtla & $17^{\circ} 33^{\prime}, 99^{\circ} 27^{\prime}$ & 1561 & 89 & 3.0 & 0.452 & 0.493 \\
11 & Gro. & Chilapa & Ayahualco & $17^{\circ} 37^{\prime}, 99^{\circ} 10^{\prime}$ & 1465 & 89 & 3.1 & 0.461 & 0.532 \\
12 & Gro. & Atlixtac & Mesones & $17^{\circ} 33^{\prime}, 98^{\circ} 52^{\prime}$ & 1703 & 100 & 3.0 & 0.472 & 0.521 \\
Mean & & & & & 92.6 & 2.9 & 0.467 & 0.521 \\
\hline
\end{tabular}

${ }^{\dagger}$ Mich.= Michoacán; Gro. $=$ Guerrero; $A=$ average number of alleles per locus; $P=\%$ of polymorphic loci; $H e=$ expected heterozygosity; Ho $=$ observed heterozygosity.

Table 2. Wright's $F$ statistics and gene flow $\left(N_{\mathrm{m}}\right)$ for twelve A. cupreata populations from the states of Michoacán and Guerrero, México.

\begin{tabular}{|c|c|c|c|c|}
\hline Locus & $\mathrm{F}_{\text {IS }}$ & $\mathrm{F}_{\mathrm{ST}}$ & $\mathrm{F}_{\mathrm{IT}}$ & $\mathrm{N}_{\mathrm{m}}$ \\
\hline Acph-1 & -0.126 & 0.043 & -0.078 & 5.63 \\
\hline Pgi-1 & -0.107 & 0.045 & -0.058 & 5.30 \\
\hline Pgi-2 & -0.094 & 0.034 & -0.057 & 7.06 \\
\hline$P g m-2$ & -0.096 & 0.044 & -0.047 & 5.39 \\
\hline$P g m-3$ & -0.115 & 0.043 & -0.067 & 5.54 \\
\hline$M e-2$ & -0.150 & 0.040 & -0.104 & 5.92 \\
\hline$M n r-1$ & -0.097 & 0.046 & -0.047 & 5.18 \\
\hline$G d h-1$ & -0.117 & 0.042 & -0.070 & 5.73 \\
\hline Got-1 & -0.142 & 0.042 & -0.094 & 5.74 \\
\hline Average & -0.118 & 0.042 & -0.071 & 5.68 \\
\hline Standard deviation & 0.054 & 0.009 & 0.053 & \\
\hline 95\% Confidence interval & -0.009 to -0.207 & 0.061 to 0.028 & -0.156 to 0.038 & \\
\hline
\end{tabular}

$F_{\mathrm{IS}}=$ inbreeding coefficient of individuals relative to subpopulations ; $F_{\mathrm{ST}}=$ inbreeding due to differentiation among populations, relative to the total population; $F_{\mathrm{IT}}=$ inbreeding of individuals relative to the total population; $N_{\mathrm{m}}=$ gene flow.

distances. Minimum viable effective population size $\left(N_{\mathrm{e}}\right)$ was estimated based on the average $H_{\mathrm{e}}$ using the linear model fitted by regressing $N$ values against $H_{\mathrm{e}}$ values, as used by Millar and Libby (1991) in several conifer species. $N_{e}$ values estimated by Millar and Libby (1991) assumed a mutation rate of $10^{-5}$ and are designed to maintain given $H_{e}$ values. The regression model proposed by Viveros-Viveros et al. (2010) was used:

$$
\begin{gathered}
N_{\mathrm{e}}=-984.58+\left(36723 H_{\mathrm{e}}\right) \\
\text { RESULTS AND DISCUSSION }
\end{gathered}
$$

\section{RESULTS AND DISCUSSION}

\section{Variation and genetic structure}

High polymorphism was found, with an average among 
Table 3. Genetic distances (above diagonal) and geographic distances (below diagonal, $\mathrm{km}$ ) for twelve A. cupreata populations from the states of Michoacán and Guerrero, México. Population numbers as in Table 1.

\begin{tabular}{|c|c|c|c|c|c|c|c|c|c|c|c|c|c|}
\hline & \multicolumn{13}{|c|}{ Nei's genetic distances } \\
\hline & Population & 1 & 2 & 3 & 4 & 5 & 6 & 7 & 8 & 9 & 10 & 11 & 12 \\
\hline \multirow{12}{*}{ 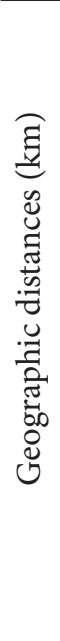 } & 1 & & 0.058 & 0.060 & 0.046 & 0.023 & 0.038 & 0.028 & 0.041 & 0.018 & 0.011 & 0.034 & 0.035 \\
\hline & 2 & 58.4 & & 0.067 & 0.018 & 0.028 & 0.052 & 0.037 & 0.070 & 0.048 & 0.028 & 0.071 & 0.020 \\
\hline & 3 & 73.9 & 15.6 & & 0.014 & 0.066 & 0.083 & 0.065 & 0.099 & 0.047 & 0.071 & 0.047 & 0.038 \\
\hline & 4 & 74.6 & 17.2 & 5.8 & & 0.012 & 0.035 & 0.033 & 0.052 & 0.031 & 0.025 & 0.032 & 0.008 \\
\hline & 5 & 81.4 & 24.0 & 9.0 & 7.54 & & 0.016 & 0.027 & 0.032 & 0.035 & 0.008 & 0.043 & 0.017 \\
\hline & 6 & 88.0 & 30.6 & 16.5 & 13.55 & 7.6 & & 0.035 & 0.086 & 0.065 & 0.027 & 0.071 & 0.057 \\
\hline & 7 & 84.5 & 28.5 & 16.2 & 11.7 & 8.6 & 5.1 & & 0.083 & 0.056 & 0.021 & 0.071 & 0.048 \\
\hline & 8 & 118.5 & 73.1 & 64.2 & 59.08 & 56.9 & 50.1 & 44.3 & & 0.051 & 0.023 & 0.047 & 0.026 \\
\hline & 9 & 238.9 & 245.1 & 249.0 & 243.8 & 247.1 & 244.1 & 239.0 & 206.5 & & 0.023 & 0.011 & 0.036 \\
\hline & 10 & 274.6 & 282.5 & 284.9 & 279.3 & 282.8 & 279.3 & 275.0 & 241.6 & 35.9 & & 0.027 & 0.016 \\
\hline & 11 & 292.7 & 294.5 & 296.1 & 290.8 & 293.0 & 289.0 & 285.2 & 249.1 & 54.6 & 30.6 & & 0.033 \\
\hline & 12 & 327.5 & 326.3 & 327.8 & 322.0 & 323.5 & 319.6 & 315.6 & 276.6 & 90.9 & 64.0 & 35.5 & \\
\hline
\end{tabular}

\section{Nei's genetic distance}
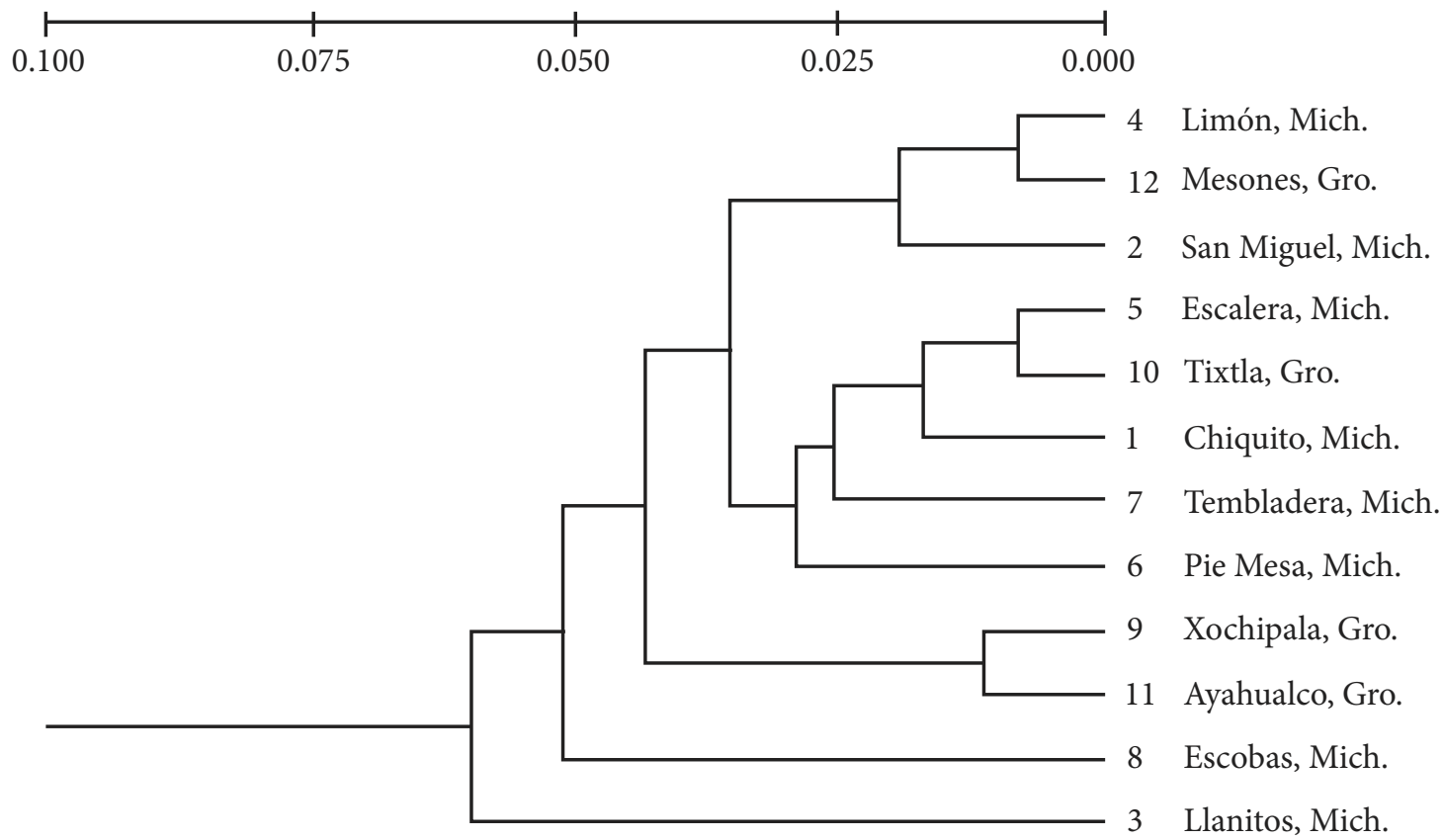

Figure 1. UPGMA dendrogram for twelve A. cupreata populations from the states of Michoacán and Guerrero, México, based on Nei (1978) genetic distances.

populations of $93 \%$ polymorphic loci and 2.9 alleles per locus. The heterozygosity was also very large, with an average expected value of $H_{e}=0.467$, and an even larger value of observed heterozygosity of $H_{\mathrm{o}}=0.521$ (Table 1 ). These values are the largest ever reported for an Agave species endemic to México (Martínez-Palacios et al., 1999; Navarro-Quezada et al., 2003; Silva-Montellano and
Eguiarte, 2003a; Demey et al., 2004). This result should be taken with caution because we used only 9 loci; there is a possibility that by examining a larger number of loci the estimated heterozygosity could be lower, if by chance our sample could be biassed. Haldane test showed that 5 out of 9 loci had significant excess of heterozygotes, in comparison to Hardy-Weinberg expectations $(\mathrm{P}<0.03)$. 
Although moderate, there is a significant genetic differentiation among populations with $F_{\mathrm{ST}}=0.042$ (95 $\%$ confidence interval from 0.0613 to 0.0281 ) (Table 2). Such differentiation is lower than the values reported for other Agave species: $F_{\mathrm{ST}}=0.08$ for A. subsimplex (NavarroQuezada et al., 2003); $F_{\mathrm{ST}}=0.083$ for A. lechuguilla (SilvaMontellano and Eguiarte, 2003a); $F_{\mathrm{ST}}=0.135$ for $A$. deserti; and $F_{\mathrm{ST}}=0.236$ for A. victoriae-reginae (Martínez-Palacios et al., 1999).

It is likely that the moderate genetic differentiation is produced by the counteracting effect of a relevant gene flow, estimated as $N_{\mathrm{m}}=5.68$ (Table 2), which might be due to the action of efficient pollinators such as bees, birds and bats (Gentry, 1982; Eguiarte et al., 2000).

Average genetic distance between pairs of populations was relatively low $(D=0.04)$. The largest genetic distance $(D=0.09)$ was found between the Escobas and Llanitos populations, both from Michoacán, while the lowest genetic distance $(D=0.008)$ was between Tixtla, Guerrero and Escalera, Michoacán (Table 3). The UPGMA dendrogram does not follow a geographic pattern since geographically distant populations clustered together (for example: Limón, Michoacán grouped with Mesones, Guerrero, both separated by $322 \mathrm{~km}$ ), while some geographically close populations did not clustered together (Figure 1). This lack of association between genetic distances and geographic locations was confirmed by the Mantel test $(\mathrm{r}=-0.110, \mathrm{P}=$ 0.769 ), which showed no significant isolation by distance.

Despite the heavy exploitation pressure to which $A$. cupreata populations are subjected, there is no evidence of inbreeding within populations: $F_{\text {IS }}=-0.1179$ (significantly different from zero, $95 \%$ confidence interval from -0.0072 to -0.2054 ), a value that indicates a significant excess of heterozygotes. This can be related to the mating system of $A$. cupreata that only reproduces sexually, their flowers display herkogamy (spatial separation of anthers and stamens) and dichogamy (temporal separation of male and female reproductive organs), and specifically protandry (earlier maturation of anthers than that of pistils); these characteristics are favoring outcrossing and apparently making self pollination nearly impossible (Illsley et al., 2007). Thus, this outcrossing system apparently plays a relevant role to prevent the accumulation of inbreeding, even when the population sizes are reduced. However, inter-specific crossing is seemingly possible, since seedlings that appear to be hybrids of $A$. cupreata with A. attenuata and $A$. inaequidens have been observed in established plantations of A. cupreata (Martínez-Palacios A. 2009; Personal comm.).

\footnotetext{
${ }^{2}$ Martínez-Palacios A, S Chávez Mendoza, M Gómez Sierra, Ma Sierra Yxta, R Cárdenas Navarro (2009) Management and Conservation of Agave cupreata (Agavaceae), (Resumenes en extenso en CD). First International Conference on Sustainable Cities. 26 al 29 de Octubre de 2009, Morelia Michoacán, México. pp:1-11
}

Estimated minimum viable effective population size was $N_{e}=16165$. This value is very large, as a result of the very large average heterozygosity value. In general, for conservation of genetic variability the suggested $N_{e}$ sizes range between 500 (Franklin, 1980; Frankham et al., 2002) and 5000 individuals (Lande 1995; Frankham et al., 2002). In our case it would be more realistic to use much more modest $N_{e}$ sizes than the estimated value (16 165), considering that natural populations of $A$. cupreata have substantially lower census sizes, perhaps a maximum of $N_{\mathrm{e}}$ $\approx 500$ (reproductive individuals flowering the same year). Thus, in order to designate A. cupreata natural populations as forest genetic resource conservation units (sensu SáenzRomero et al., 2003, based on Ledig [1988], Millar and Libby [1991]), the largest populations would need to be located and protected.

\section{Considerations for conservation}

A sustainable management program of A. cupreata that allows continuous harvesting of mature individuals for mescal distillation needs to gradually satisfy the demand of this beverage by relying more on commercial plantations, rather than in natural populations. In parallel, it would be needed to protect natural populations and to establish additional ones to be managed as forest genetic resource conservation units (FGRCUs). Provided that the estimated minimum viable effective population size $\left(N_{\mathrm{e}}\right)$ for such FGRCUs is larger than the actual largest natural populations, it would be required to establish plantations between large natural populations, to serve as corridors for pollinators, in order to maintain the genetic flow among populations and also for increasing $N_{e}$, counterbalancing in that way the loss of individuals that could have occurred due to past harvesting. On this regard, although the recent establishment of commercial plantations of $A$. cupreata aided by subsidies from the federal, state and municipality governments seems to be a measure in the correct direction, it might be needed to establish additional plantations with the main goal of conservation, and not only for commercial harvesting.

The predicted decoupling between genotypes and climate due to factual climatic change could be diminished if new commercial plantations are established at altitudes higher than those of present populations, in order to match genotypes fitness to predicted future climates. Although it is generally suggested to plant at an elevation $300 \mathrm{~m}$ higher than the seed source, to match the climate predicted for 2030 (Sáenz-Romero et al., 2010), it is recommended to make decisions based on estimations for contemporary and future climate for specific locations, using available resources, including web based tools (e.g. Crookstone, 2011).

\section{CONCLUSIONS}

Agave cupreata populations have a very large expected 
heterozygosity $(H=0.467)$, with an excess of observed heterozygotes $\left(H_{\mathrm{o}}^{\mathrm{e}}=0.521, F_{\mathrm{IS}}=-0.1179\right)$. The genetic differentiation among populations is relatively low $\left(F_{\mathrm{ST}}=\right.$ 0.042 ), yet statistically significant. There is not significant isolation by distance. Estimated minimum viable effective population size was very large $\left(N_{\mathrm{e}}=16165\right)$, due to the large heterozygosity values.

\section{ACKNOWLEDGEMENTS}

Financial support was provided to Alejandro MartínezPalacios by the joint research fund for basic research between the Mexican National Council of Science and Technology (CONACYT) and the Mexican Ministery of Education (SEP, project -2004-P47777-Z), the Scientific Research Council (CIC) of the Universidad Michoacana de San Nicolás de Hidalgo (UMSNH, project 5.6) and the State of Michoacán Council of Science and Technology (COECYT-Michoacán, Project CB0702122-8). Three anonymous reviewers contributed to significantly improve the manuscript.

\section{BIBLIOGRAPHY}

Barraza-Morales A, F L Sánchez-Teyer, M Robert, M Esqueda, A Gardea (2006) Variabilidad genética en Agave angustifolia Haw. de la sierra Sonorense, México, determinada con marcadores AFLP. Rev. Fitotec. Mex. 29:1-8.

Chase M W, J L Reveal, M F Fay (2009) A subfamilial classification for the expanded asparagalean families Amaryllidaceae, Asparagaceae and Xanthorrhoeaceae. Bot. J. Linnean Soc. 161:132-136.

Cheliak W M, J A Pitel (1984) Electrophoretic identification of clones in trembling aspen. Can. J. For. Res. 14:740-743.

Colunga-GarcíaMarín P, D Zizumbo-Villarreal (2007) El tequila y otros mezcales del centro-occidente de México: domesticación, diversidad y conservación de germoplasma. In: En lo Ancestral hay Futuro: del Tequila, los Mezcales y otros Agaves. P ColungaGarcíaMarín, L Eguiarte, A Larqué, D Zizumbo-Villarreal (eds). CICY-CONACYT-CONABIO-SEMARNAT-INE. México D.F. pp:113-131.

Conkle M T, P D Hodgskiss, L B Nunnally, S C Hunter (1982) Starch gel electrophoresis of conifer seeds: a laboratory manual. General Technical Report PSW-64. Pacific Southwest Forest and Range xperiment Station. United States Forest Service. Berkeley, California. $18 \mathrm{p}$.

Crookstone N L (2011) Custom Data Requests. In: Research on Forest Climate Change: Potential Effects of Global Warming on Forests and Plant Climate Relationships in Western North America and Mexico. Moscow Forestry Sciences Laboratory, Rocky Mountain Research Station, USDA Forest Service. Available at: http://forest. moscowfsl.wsu.edu/climate/customData/ (May 2011).

Demey J R, E Gamez, S Molina, D Infante (2004) Comparative study of the discriminating capacity of AFLP and ISTR markers for genetic analysis of Agave fourcroydes. Plant Mol. Biol. Rep. 22:29-35.

Eguiarte L E, V Souza, A Silva-Montellano (2000) Evolución de la familia Agavaceae: filogenia, biología reproductiva y genética de poblaciones. Bol. Soc. Bot. Méx. 66:131-150.

Eguiarte L E, V Souza (2007) Historia natural del Agave y sus parientes: Evolución y ecología. In: En lo Ancestral hay Futuro: del Tequila, los Mezcales y otros Agaves. P Colunga-GarcíaMarín, L Eguiarte, A Larqué, D Zizumbo-Villarreal (eds). CICY-CONACYTCONABIO-SEMARNAT-INE. México D.F. pp:3-21.

Franklin I R (1980) Evolutionary change in small populations. In: Conservation Biology: an Evolutionary-Ecological Perspective. M E Soulé, B A Wilcox (eds). Sinauer. Sunderland, MA, U.S.A. pp:135-150.

Frankham R, J D Ballou, DA Briscoe (2002) Introduction to Conservation Genetics. Cambridge University Press. Cambridge, UK. 617 p.

Gentry S H (1982) Agaves of Continental North America. Univ. Arizona
Press. Tucson, AZ. 669 p.

Haldane J B S (1954) An exact test for randomness of mating. J. Genetics 52:631-635

Illsley C, E Vega, I Pisanty, A Tlacotempa, P García, P Morales, G Rivera, J García, V Jiménez, F Castro, M Calzada (2007) Maguey papalote: hacia el manejo campesino de un recurso colectivo en el trópico seco de Guerrero, México. In: En lo Ancestral hay Futuro: del Tequila, los Mezcales y otros Agaves. P ColungaGarcíaMarín, L Eguiarte, A Larqué, D Zizumbo-Villarreal (eds). CICY-CONACYT-CONABIO-SEMARNAT-INE. México D.F. pp:319-338.

Lande R (1995) Mutation and conservation. Conserv. Biol. 9:782-791.

Ledig F T (1988) The conservation of diversity in forest trees. Why and how should genes be conserved? Bioscience 38:471-479.

Manly B F J (1987) The Statistics of Natural Selection on Animal Populations. Chapman and Hall. New York, N.Y., USA. 484 p.

Martínez-Palacios A, L E Eguiarte, G R Furnier (1999) Genetic diversity of endangered endemic Agave victoriae-reginae (Agavaceae) in Chihuahuan desert. Am. J. Bot. 86:1093-1098.

Millar C I, W J Libby (1991) Strategies for conserving clinal, ecotypic, and disjunct population diversity in widespread species. In: Genetics and Conservation of Rare Plants. D A Falk, K E Holsinger (eds). Oxford University Press. New York. pp:149-170.

Miller M P (1997) Tools for Population Genetics Analyses (TFPGA) 1.3: A windows program for the analysis of allozyme and molecular population genetic data. Computer software distributed by author. Available at: http://www.marksgeneticsoftware.net/_vti_bin/ shtml.exe/tfpga.htm (May 2010).

Navarro-Quezada A, R González-Chauvet, F Molina-Freaner, L E Eguiarte (2003) Genetic differentiation in the Agave deserti (Agavaceae) complex of the Sonoran desert. Heredity 90:220-227.

Nei M (1978) The theory of genetic distance and evolution of human races. J. Human Genet. 23:341-369.

Pitel J A, W M Cheliak (1984) Effect of extraction buffers on characterization of isoenzymes from vegetative tissues of five conifers species: a user's manual. Information Report PI-X-34, Petawawa National Forestry Institute. Canadian Forestry Service. Chalk River, Ontario, Canada. 64 p.

Sáenz-Romero C, A E Snively, R Lindig-Cisneros (2003) Conservation and restoration of pine forest genetic resources in México. Silvae Genet. 52:233-237.

Sáenz-Romero C, G E Rehfeldt, N L Crookston, P Duval, R StAmant, J Beaulieu, B A Richardson (2010) Spline models of contemporary, 2030, 2060 and 2090 climates for México and their use in understanding climate-change impacts on the vegetation. Climatic Change 102:595-623.

SEDRU, Secretaría de Desarrollo Rural (2009) Exigen productores de mezcal en Michoacán la denominación de origen de su producto. Secretaría de Desarrollo Rural. Gobierno del Estado de Michoacán. Morelia, Mich. Available at: http://www.michoacan.gob.mx/ SEDRU/Exigen_productores_de_mezcal_en_Michoacan_la_ denominacion_de_origen_de_su_producto (July 2009).

Silva-Montellano A, L E Eguiarte (2003a) Geographic patterns in the reproductive ecology of Agave lechuguilla (Agavaceae) in the Chihuahuan desert. I. Floral characteristics, visitors and fecundity. Am. J. Bot. 90:377-387.

Silva-Montellano A, L E Eguiarte (2003b) Geographic patterns in the reproductive ecology of Agave lechuguilla (Agavaceae) in the Chihuahuan desert. II. Genetic variation, differentiation and inbreeding estimates. Am. J. Bot. 90:700-706.

Snedecor G W, W G Cochran (1967) Statistical Methods, 6th ed. The Iowa State University Press. Ames, IA. 593 p.

Soltis D E, C H Haufler, D C Darrow, G J Gastrony (1983) Starch gel electrophoresis of ferns: a compilation of grinding buffers, and staining schedules. Amer. Fern J. 73:9-27.

Stuber C W, J F Wendel, M M Goodman, J S C Smith (1988) Techniques and scoring procedures for starch gel electrophoresis of enzymes from maize (Zea mays L.). Technical Bulletin 286. North Carolina State University. Raleigh, N.C., EUA. 87 p.

Viveros-Viveros H, B L Tapia-Olivares, C Sáenz-Romero, J J VargasHernández, J López-Upton, A Santacruz-Varela, G RamírezValverde (2010) Isoenzymatic variation of Pinus hartwegii Lindl. along an altitudinal gradient in Michoacán, México. Agrociencia 44:723-733. 
Wendel J F, N F Weeden (1989) Visualization and interpretation of plant isozymes. In: Isozymes in Plant Biology. D E Soltis, P S Soltis (eds). Chapman and Hall. London, UK. pp:5-45.

Wright S (1965) The interpretation of population structure by $F$-statistics with special regard to systems of mating. Evolution 19:395-420.

Yeh F C, D M O'Malley (1980) Enzyme variation in natural populations of Douglas-fir, (Pseudotsuga menziessii (Mirb.) Franco) from British Columbia. I. Genetic variation patterns in coastal populations. Silvae Genet. 29:83-92.
Zizumbo-Villarreal D, P Colunga-GarcíaMarín (2007) La introducción de la destilación y el origen de los mezcales en el occidente de México. In: En lo Ancestral hay Futuro: del Tequila, los Mezcales y otros Agaves. P Colunga-GarcíaMarín, L Eguiarte, A Larqué, D Zizumbo-Villarreal (eds). CICY-CONACYT-CONABIOSEMARNAT-INE. México D.F., pp:85-112. 